\title{
New taxa of Neosartorya and Aspergillus in Aspergillus section Fumigati
}

\author{
Seung-Beom Hong · Hyeon-Dong Shin · Joonbae Hong · Jens C. Frisvad • \\ Per V. Nielsen · János Varga · Robert A. Samson
}

Received: 21 March 2007/ Accepted: 8 June 2007/Published online: 4 July 2007

(C) Springer Science+Business Media B.V. 2007

\begin{abstract}
Three new species of Neosartorya and one new Aspergillus of section Fumigati are proposed using a polyphasic approach based on morphology, extrolite production and partial $\beta$-tubulin, calmodulin, and actin gene sequences. The phylogenetic analyses using the three genes clearly show that the taxa grouped separately from the known species and confirmed the phenotypic differences. Neosartorya
\end{abstract}

Electronic supplementary material The online version of this article (doi:10.1007/s10482-007-9183-1) contains supplementary material, which is available to authorized users.

\section{S.-B. Hong}

Korean Agricultural Culture Collection, NIAB, Suwon 441-707, South Korea

\section{H.-D. Shin}

Division of Environmental Science and Ecological Engineering, College of Life and Environmental Sciences, Korea University, Seoul 136-701, South Korea

J. Hong

Consumer Safety Center, Korea Consumer Agency,

Seoul 137-700, South Korea

J. C. Frisvad · P. V. Nielsen

Center for Microbial Biotechnology, Biocentrum-DTU, Technical University of Denmark, Building 221,

Kgs. Lyngby 2800, Denmark

J. Varga $\cdot$ R. A. Samson $(\bowtie)$

CBS Fungal Biodiversity Centre, Uppsalalaan 8, 3584

CT Utrecht, The Netherlands

e-mail: samson@cbs.knaw.nl denticulata is characterized by its unique denticulate ascospores with a prominent equatorial furrow; $N$. assulata by well developed flaps on the convex surface of the ascospores which in addition have two distinct equatorial crests and $N$. galapagensis by a funiculose colony morphology, short and narrow conidiophores and ascospores with two wide equatorial crests with a microtuberculate convex surface. Aspergillus turcosus can be distinguished by velvety, gray turquoise colonies and short, loosely columnar conidial heads. The four new taxa also have unique extrolite profiles, which contain the mycotoxins gliotoxin and viriditoxin in $N$. denticulate; apolar compounds provisionally named NEPS in N. assulata and gregatins in N. galapagensis. A. turcosus produced kotanins. $N$. denticulata sp. nov., $N$. assulata sp. nov., N. galapagensis sp. nov., and A. turcosus sp. nov. are described and illustrated.

Keywords Actin - Aspergillus turcosus . Calmodulin · Extrolites - DNA sequencing · Neosartorya denticulata $\cdot N$. assulata . $N$. galapagensis $\cdot \beta$-Tubulin

\section{Introduction}

Aspergillus section Fumigati and its teleomorph Neosartorya include many species which are important because they can be pathogenic or allergenic to man (Brakhage and Langfelder 2002), cause food 
spoilage and produce mycotoxins (Cole and Cox 1981). Certain species also produce interesting bioactive extrolites that are potential drug candidates (Turner and Aldridge 1983). Section Fumigati currently includes now 26 Neosartorya species and nine anamorph species (Pitt et al. 2000; Samson 2000; Horie et al. 2003; Hong et al. 2005, 2006).

During a survey of Aspergillus and Penicillium species from Korea, many isolates belonging to section Fumigati were isolated. These isolates were compared to known taxa and those present at the CBS and IBT culture collections which were atypical or unidentified, using a polyphasic approach (Frisvad and Samson 2004). We have examined the macro- and micromorphology, extrolite profiles and $\beta$-tubulin, calmodulin, and actin gene sequences of the isolates, and based on the above data, here we describe four new species in Aspergillus section Fumigati.

\section{Materials and methods}

\section{Morphological examinations}

For macro-morphological observations, isolates were cultivated on Czapek yeast autolysate (CYA), malt extract agar (MEA), CZ agar (CZA), and oatmeal agar (OA) (Samson et al. 2004). The isolates were inoculated at three points on each plate of each medium and incubated at $25^{\circ} \mathrm{C}$ in the dark for 7 days, and additionally at $37^{\circ} \mathrm{C}$ on CYA. For microscopic observations, mounts were made in lactic acid from MEA colonies; a drop of alcohol was added to remove air bubbles and excess conidia. Scanning Electron Microscopy (SEM) was performed using a Hitachi S570 electron microscope. For SEM, mature cleistothecia were transferred to aluminum stubs with double sided adhesive tape. A small drop of $10 \mathrm{mM}$ ACES buffer containing $0.05 \%$ Tween- 80 was added and the cleistothecia crushed. The suspension was air dried and coated with platinum.

DNA analyses

Isolates used for sequence analyses are listed in Table 1. Genomic DNA was extracted according to the procedure described by Lee and Taylor (1990). The $5^{\prime}$ portion of the $\beta$-tubulin gene (benA) was amplified using primers bt $2 \mathrm{a}$ and bt $2 \mathrm{~b}$ (Glass and
Donaldson 1995). Amplifications of the partial calmodulin and actin genes were set up as described previously (Hong et al. 2005). The amplified DNA fragments were purified by QIAquick PCR purification kits (Qiagene, Hilden, Germany). DNA sequences were determined using BigDye Terminator v3.1 Cycle Sequencing kit (ABI 0401041, Foster, CA, USA) and ABI 3100 DNA sequencer. Both strands of each fragment were sequenced using the same primers.

DNA sequences were edited with the DNASTAR computer package. Sequence alignments were performed by using CLUSTAL W (Thompson et al. 1994) and improved manually. The neighbor-joining (NJ) method was used for the phylogenetic analysis. Evolutionary distances between the sequences were calculated by Kimura's formula (Kimura 1980) using the program DNADIST of the PHYLIP program package (Felsenstein 1995). Phylogenetic trees were prepared by the NJ method (Saitou and Nei 1987) using the program NEIGHBOR of the PHYLIP package. Bootstrap values were calculated from 1,000 replications of the bootstrap procedure using programs SEQBOOT, DNADIST, NEIGHBOR, and CONSENSE of the package (Felsenstein 1995).

For parsimony analysis, the PAUP* Version 4.0 software was used (Swofford 2002). Alignment gaps were treated as a fifth character state and all characters were unordered and of equal weight. Maximum parsimony analysis was performed for all data sets using the heuristic search option with 100 random taxa additions and tree bisection and reconstruction (TBR) as the branch-swapping algorithm. Branches of zero length were collapsed and all multiple, equally parsimonious trees were saved. The robustness of the trees obtained was evaluated by 1,000 bootstrap replications (Hillis and Bull 1993). An Aspergillus clavatus isolate was used as outgroup in these experiments.

The $\beta$-tubulin, calmodulin and actin gene sequences, determined in this study, have been deposited in GenBank and the accession numbers are listed in Table 1.

\section{Analysis for extrolites}

The isolates were grown at $25^{\circ} \mathrm{C}$ for 1 week on CYA and YES in the dark and extracted according to Smedsgaard (1997). Extrolites were analyzed by 


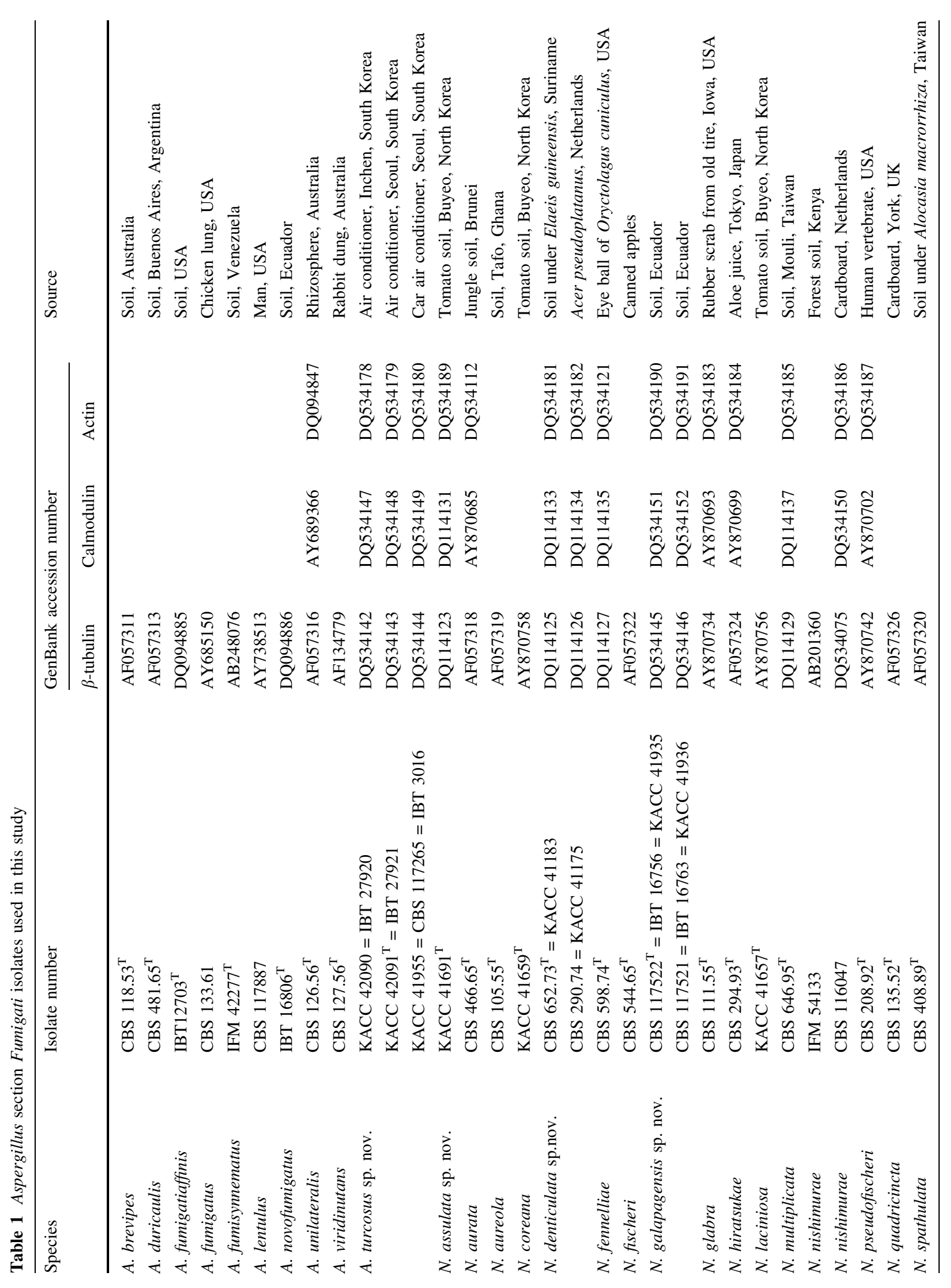


HPLC using alkylphenone retention indices and diode array UV-VIS detection as described by Frisvad and Thrane (1987), as modified by Smedsgaard (1997).

\section{Results and discussion}

Molecular studies

For the phylogenetic analysis of $\beta$-tubulin sequences, most accepted species in section Fumigati except Neosartorya indohii, N. sublevispora, and N. tsurutae were included to determine the phylogenetic positions of the putatively new species (Fig. 1). For the calmodulin and actin datasets only sequences of closely related species were included (Suppl. Figs 1, 2). 468 nucleotides of the $\beta$-tubulin gene were analyzed. Among the 225 polymorphic sites, 126 were found to be phylogenetically informative. The topology of the NJ tree is the same as one of the 28 most parsimonious trees inferred by the PAUP program (length: 441 steps, consistency index: 0.7143, and retention index: 0.6993). The calmodulin data set included 538 characters, with 87 parsimony informative characters (tree length: 272, consistency index: 0.8051, and retention index: 0.7706). The actin data set included 394 characters, with 66 parsimony informative characters (tree length: 200, consistency index: 0.7900, and retention index: 0.7801).

The cladograms based on $\beta$-tubulin, calmodulin, and actin gene sequences revealed that isolates CBS 652.73 and CBS 290.74, which had identical sequences at each loci, were related to the heterothallic species $N$. fennelliae, but the similarity between this species and the two isolates was quite low $(96.5 \%$ in the $\beta$-tubulin gene partition and 97.8 $98.4 \%$ in the calmodulin gene partition). These two strains had unique ascospore ornamentations, with denticulate convex surfaces and a prominent equatorial furrow (Fig. 2) and could be easily microscopically differentiated from any other Neosartorya species (Samson et al. 1990; Horie et al. 2003). Both isolates produced gliotoxin, while CBS 652.73 also produced viriditoxin. Gliotoxin is also produced by A. fumigatus and N. pseudofischeri, but there were several differences in the profile of extrolites in $N$. pseudofischeri and these isolates (data not shown). A. fumigatus and N. pseudofischeri are among the 
Fig. 1 Taxonomic position of some new species in Aspergillus section Fumigati inferred from Neighbor-Joining analysis of partial $\beta$-tubulin gene sequences. The numbers above/below the nodes represent bootstrap values of $>60 \%$ (out of 1,000 bootstrap replications). The number of nucleotide changes is represented by branch length

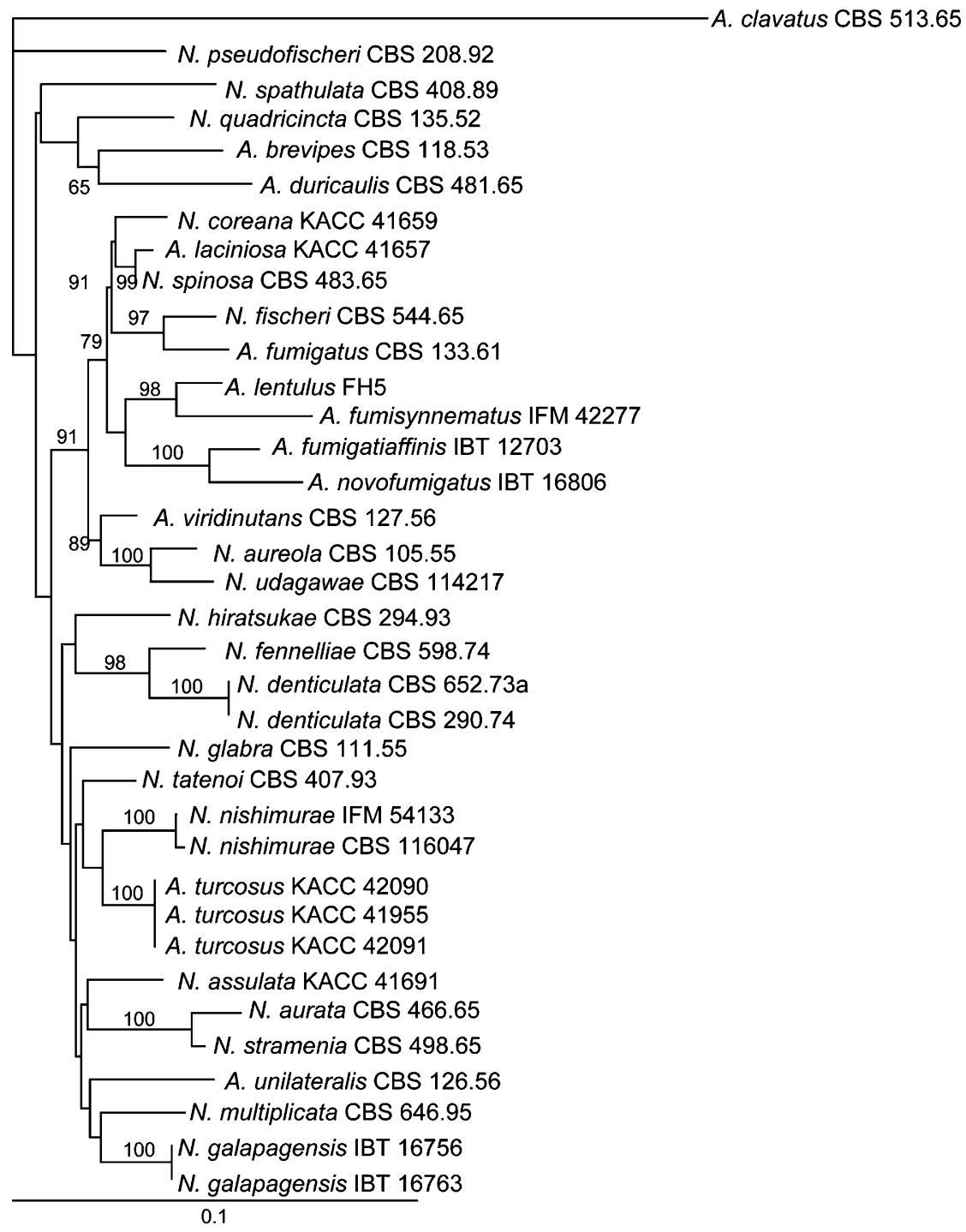

most divergent species in the group (Geiser et al. 1998; Horie et al. 2003; Hong et al. 2005, 2006; Varga et al. 2000), yet they share the production of this mycotoxin. Here we describe CBS 652.73 and CBS 290.74 as $N$. denticulata sp. nov.

Isolate KACC 41691 did not show a clear relationship to any species in the $\beta$-tubulin phylogeny, but was closest to CBS 116047 based on calmodulin and actin sequence data (Suppl. Figs 1, 2). CBS 116047 is best accommodated as N. nishimurae. However, isolate KACC 41691 is homothallic, whereas $N$. nishimurae is heterothallic. This isolate has similar morphological characteristics to
N. pseudofischeri, but our genotypic analyses indicate that they are phylogenetically distinct. KACC 41691 produces ascospores with several large flaps and two distinct equatorial crests (Fig. 3). These characteristics are similar to those of $N$. pseudofischeri in which the ascospores also have triangular flaps on a convex surface (Peterson 1992), but in KACC 41691 the flaps are more pronounced. Furthermore, KACC 41691 differs from $N$. pseudofischeri by its growth rates on MEA and CZA (after 7 days at $25^{\circ} \mathrm{C}$ colonies were 49-58 and 24-42 mm, respectively, for KACC 41691, and 90, and 60-70 mm for N. pseudofischeri). The ascomatal initials in $N$. pseudofischeri are 

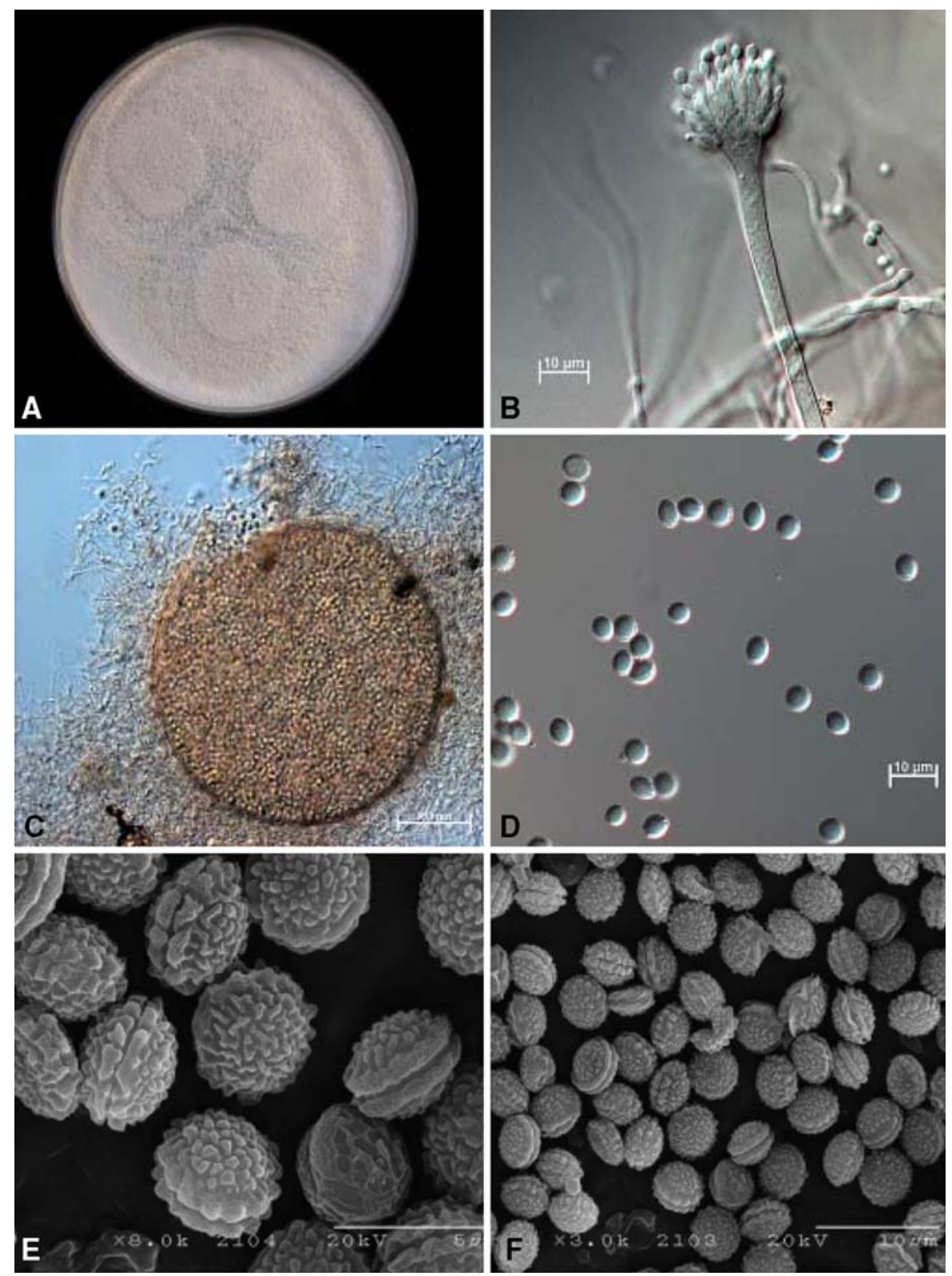

Fig. 2 Neosartorya denticulata sp. nov. (A) colonies on OA after 28 days of incubation, (B) aspergillum, (C) ascoma, (D) ascospores under a light microscope, $(\mathbf{E})$ and $(\mathbf{F})$ ascospores by SEM

characterized by many coiled hyphae whereas the initial in KACC 41691 is simpler. Ascospores are larger (5.1-6.0 $\mu \mathrm{m}$ in KACC 41691, while 4.5-5 $\mu \mathrm{m}$ in $N$. pseudofischeri). We could not detect any known extrolites in KACC 41691 but it produced partially characterized apolar compounds in common with several Neosartorya species. Here we propose the name $N$. assulata sp. nov. for isolate KACC 41691.
Isolates CBS 117522 and CBS 117521, both isolated from soil from the Galapagos Islands, were phylogenetically distinct from all other species within section Fumigati (Fig. 1, Suppl. Figs 1, 2). The colony texture of these two isolates is funiculose with conidiophores which arise from bundles of aerial hyphae. These conidiophore structures resemble as described by Horie et al. (1993) for A. fumisynnematus, but in this species the conidophores are longer, 

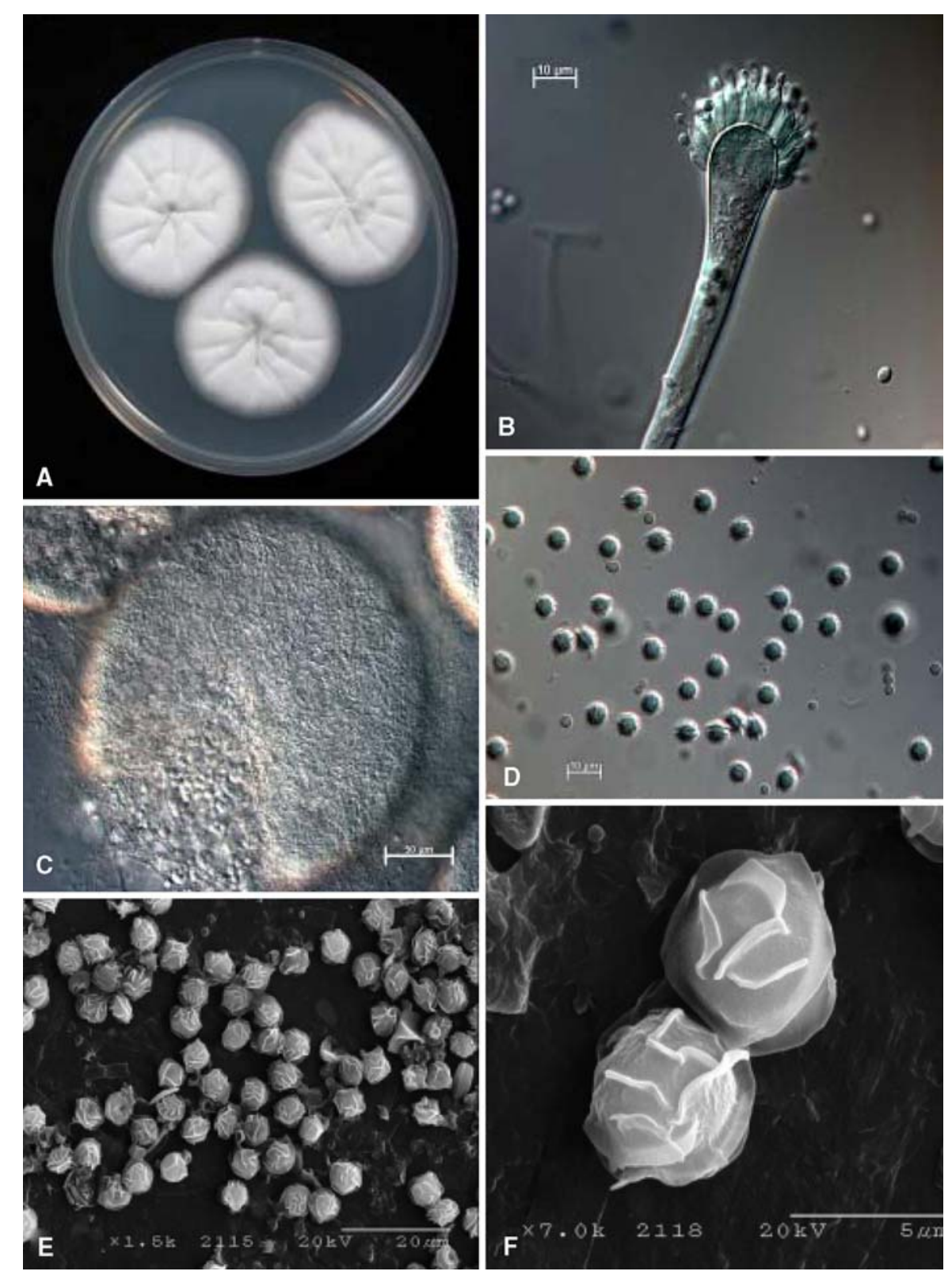

Fig. 3 Neosartorya assulata sp. nov. (A) colonies on CYA after 7 days of incubation, (B) aspergillum, (C) ascoma, (D) ascospores under a light microscope, $(\mathbf{E})$ and $(\mathbf{F})$ ascospores by SEM

up to $210 \mu \mathrm{m}$, with larger vesicles (16-20(25) $\mu \mathrm{m}$ in diam.). Ascomata were produced in 2 weeks-old colonies and ascospores were released after about 3 weeks. Ascospores resemble those of N. glabra and $N$. laciniosa, and have two conspicuous equatorial crests with a microtuberculate convex surface (Fig. 4). Isolates CBS 117522 and 117521 produced gregatins and several other extrolites not yet found in other Neosartorya or Aspergillus species, and appeared to be chemically unique. Gregatins have previously been found in A. panamensis in section Sparsi (Anke et al. 1980, 1988; Peterson 2000).

Here we describe isolates CBS 117522 and CBS 117521 as $N$. galapagensis sp. nov.

Isolates KACC 42090, KACC 42091, and KACC 41955 also showed a distinct taxonomic position 

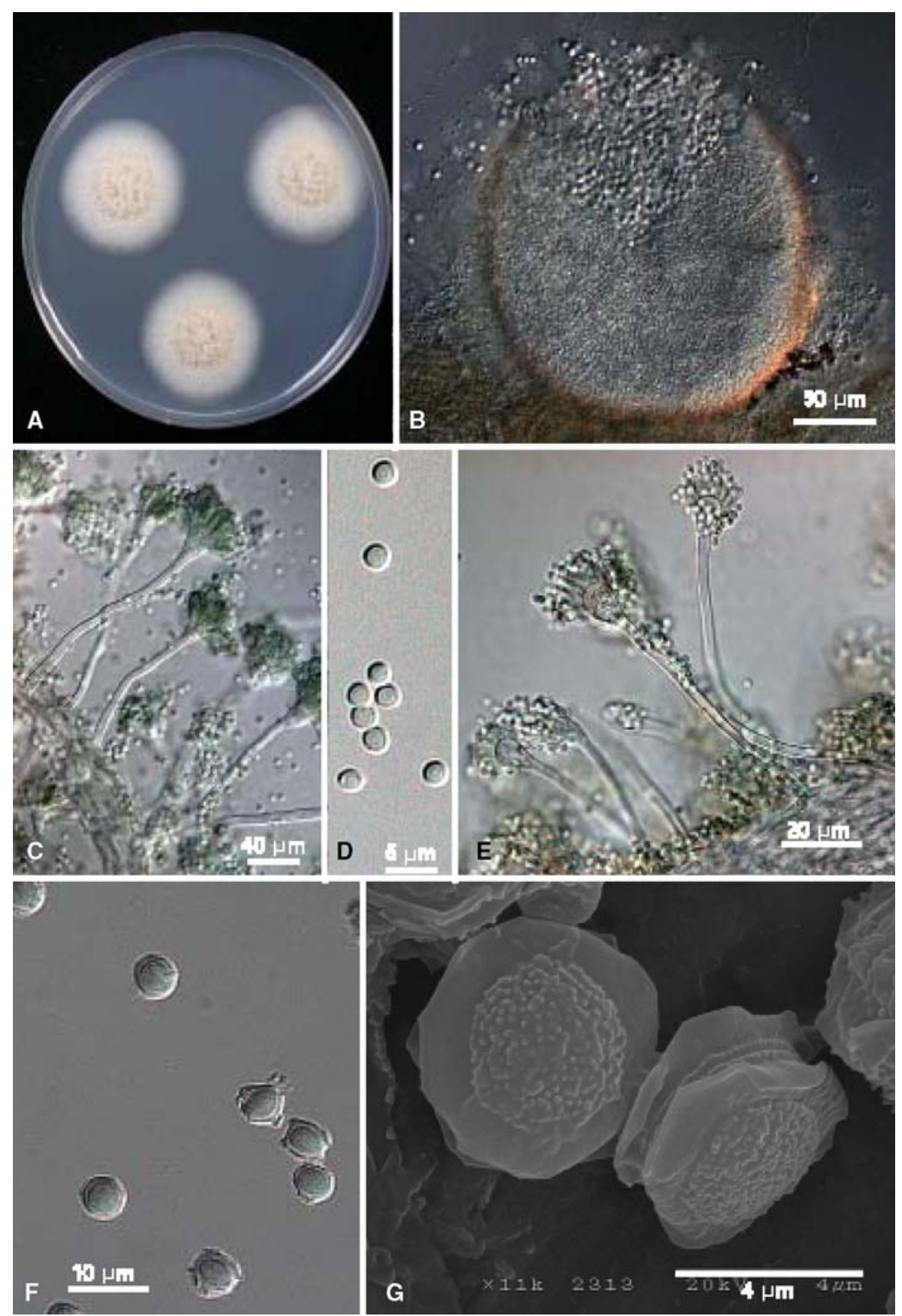

Fig. 4 Neosartorya galapagensis sp. nov. (A) colonies on CYA after 7 days of incubation, (B) ascoma, (C) and (E) stipes and conidial heads arisen from hyphal bundle, (D) conidia

within section Fumigati in the three gene phylogenies. The closest taxon to these three isolates in the $\beta$-tubulin and calmodulin gene phylogenies was the heterothallic species N. nishimurae (Fig. 1, Suppl. Fig. 1). However, the similarity of $\beta$-tubulin under a light microscope, (F) ascospores under a light microscope, $(\mathbf{G})$ ascospores by SEM

sequences between the two species was only $96.9 \%$ which is close to that observed between $N$. fischeri and $N$. spinosa (data not shown). Although A. fumigatus, A. lentulus, A. viridinutans, A. fumigatiaffinis, and $A$. novofumigatus share similar morphological 
characteristics with these three isolates, these species showed comparatively low $\beta$-tubulin gene sequence similarities of 89.8, 91.6, 93.6, 92.3, and 92.7\%, respectively. Isolates KACC 42090, 42091, and 41955 did not produce any teleomorph structure after incubation for 28 days on CYA, MEA, CZA, and OA at $25^{\circ} \mathrm{C}$. During mating experiments, all of the pairings with $N$. fennelliae, $N$. nishimurae, $N$. spathulata, N. udagawae, and between conidial strains failed to yield cleistothecia. Some conidiophore characters suggest a similarity to A. fumigatus and A. lentulus, but these isolates are different from A. fumigatus by the vesicles which are fertile over the upper two-thirds and has short, loosely columnar conidial heads. These isolates are different from A. lentulus by their velvety and gray turquoise colonies. These isolates grow at 10 and $50^{\circ} \mathrm{C}$ on MEA and CZA. On the contrary, A. fumigatus does not grow at $10^{\circ} \mathrm{C}$, while $A$. lentulus, A. fumigatiaffinis, and $A$. novofumigatus are unable to grow at $50^{\circ} \mathrm{C}$ (Hong et al. 2005). Isolates KACC 42091, 42090, and 41955 were also chemically unique. The extrolites produced by the isolates described here are typical for Aspergillus section Fumigati (data not shown). The three isolates also produced kotanins, previously found in species in less obviously related groups of Aspergillus, such as A. niger from section Nigri and A. clavatus from section Clavati (Turner and Aldridge 1983). Here we describe isolates KACC 42090, KACC 42091, and KACC 41955 as A. turcosus sp. nov.

The list of 26 known species of Neosartorya and nine anamorph species from the section Fumigati (Horie et al. 2003; Hong et al. 2005, 2006) is still expanding. With the species proposed here, there are now 29 Neosartorya species and 10 Aspergillus species in this group, 39 species in total. Unfortunately, some of the recently described species are not available for the scientific community, such as $N$. indohii, N. nishimurae, N. otanii, $N$. sublevispora, N. takakii, and N. tsurutae.

\section{Taxonomy}

Neosartorya denticulata Samson, S.B. Hong and Frisvad. sp. nov. (Fig. 2).

Species homothallica; ascomata superficialia, luteo-alba vel dilute lutea, globosa vel subglobosa, $140-230 \mu \mathrm{m}$ in diam., hyphis hyalinis vel luteolis laxe textis circumdata. Asci 8-spori, globosi vel subglobosi, 12-14 $\mu \mathrm{m}$ diam. Ascosporae lenticulares, 4-5 $\mu \mathrm{m}$ diam, denticulatae. Conidiophora ex hyphis aeriis oriunda, 3-4.5 $\mu \mathrm{m}$ lata; conidiorum capitula columnaria sed brevia, uniseriata, vesiculae spathulatae vel subclavatae, $7-12 \mu \mathrm{m}$ diam; phialides $7.5-9 \times 2-3 \mu \mathrm{m}$, didimidium superius vesiculae occupantes. Conidia subglobosa vel late ellipsoidea, levia, 2-3 $\mu \mathrm{m}$ diam.

Holotype of $N$. denticulata, here designated as CBS $652.73^{\mathrm{T}}$ (dried culture), isolated from soil in Suriname.

Homothallic, cleistothecia superficial, yellowish white to pale yellow, globose to subglobose, $140-230 \mu \mathrm{m}$ in diam., surrounded by a loose covering of hyaline to yellowish white hyphae. Asci 8-spored, globose to subglobose $12-14 \mu \mathrm{m}$, evanescent at maturity. Ascospores, 4-5 $\mu \mathrm{m}$, denticulate with a prominent equatorial furrow. Mycelium composed of hyaline, branched, septate, smooth-walled hyphae. Conidial heads short, columnar. Conidiophores arising from aerial hyphae, uniseriate, stipes 3-4.5 $\mu \mathrm{m}$ wide; vesicles spathulate to subclavate, $7-12 \mu \mathrm{m}$ in diam.; phialides 7.5-9 $\times 2-3 \mu \mathrm{m}$, covering the upper half of vesicle. Conidia subglobose to broadly elliptical, smooth, 2-3 $\mu \mathrm{m}$. Colonies on MEA growing rapidly, $35-40 \mathrm{~mm}$ in 7 days at $25^{\circ} \mathrm{C}$, white. Conidial heads produced only in colony margins. Colonies on CYA, 22-24 mm in 7 days at $25^{\circ} \mathrm{C}$, $35-38 \mathrm{~mm}$ in 7 days at $37^{\circ} \mathrm{C}$, white, loosely overgrown by aerial hyphae in center, weakly sulcate in marginal area. Conidial heads few in number. Reverse yellowish white to pale yellow (12A23) (Kornerup and Wanscher 1978).

Extrolites: The two isolates produced the mycotoxin gliotoxin. CBS 652.73 was a particularly strong producer, and also produced the mycotoxin viriditoxin. Furthermore, the two isolates produced some unique, yet unelucidated secondary metabolites.

Additional isolates: CBS $290.74=$ KACC41175, from Acer pseudoplatanus, The Netherlands.

Distinguishing features: Denticulate ascospores with a prominent equatorial furrow and the production of gliotoxin.

Neosartorya assulata S.B. Hong, Frisvad and Samson. sp. nov. (Fig. 3).

Species homothallica; ascomata superficialia, alba vel luteo-alba, globosa vel subglobosa, $150-250 \mu \mathrm{m}$ diam, hyphis hyalinis vel luteolis laxe textis circumdata. 
Asci 8-spori, globosi vel subglobosi, 14-16 $\mu \mathrm{m}$ diam. Ascosporae lenticulares, 5-6 $\mu \mathrm{m}$ diam, duabus cristis distantibus praeditae, valvis nonnullis distinctis longis intumescentii ornamentatae. Conidiophora hyalina, 3-7.5 $\mu \mathrm{m}$ lata; conidiorum capitula columnaira, brevia, uniseriata; vesicula subclavata, $10-18 \mu \mathrm{m}$ diam. Phialides 7-9 $\times 2-3 \mu \mathrm{m}$, didimidium superius vesiculae occupantes. Conidia subglobosa vel late ellipsoidea, levia, 2-3 $\mu \mathrm{m}$ diam.

Holotype of N. assulata, here designated as KACC $41691^{\mathrm{T}}$ (dried culture), isolated from soil, tomato field, Buyeo, North Korea.

Homothallic, cleistothecia superficial, white to yellowish white, globose to subglobose, $150-250 \mu \mathrm{m}$ in diam. Asci 8-spored, globose to subglobose 14-16 $\mu \mathrm{m}$, evanescent at maturity. Ascospores lenticular, spore body $5.0-6.0 \mu \mathrm{m}$, with two well-separated equatorial crests and convex surface decorated with several large, round flaps. Mycelium composed of hyaline, branched, septate, smooth-walled hyphae. Conidial heads short, columnar. Conidiophores arising from aerial hyphae and substrate, 3-7.5 $\mu \mathrm{m}$ wide; vesicles subclavate, 10-18 $\mu \mathrm{m}$ in diam., uniseriate, phialides 7-9 $\mu \mathrm{m}$, covering the upper half of vesicles. Conidia, subglobose to broadly elliptical, ovoid, smooth, 2-3 $\mu \mathrm{m}$. Colonies on MEA, $49-58 \mathrm{~mm}$ in 7 days at $25^{\circ} \mathrm{C}$, white, radially weak sulcate. Conidial heads aerial, numerous. Colonies white on CYA, $37-41 \mathrm{~mm}$ at $25^{\circ} \mathrm{C}, 64-68 \mathrm{~mm}$ at $37^{\circ} \mathrm{C}$ in 7 days. Radially and roundly sulcate, with some clear exudates. Conidial heads aerial, abundant. Reverse yellowish white (1A2) to pale yellow (1A3) (Kornerup and Wanscher 1978).

Extrolite profile: This species is characterized by relatively weak production of secondary metabolites. It does produce some indole alkaloids and some apolar metabolites.

Distinguishing features: Large, round flaps on convex surface of ascospores with two distinct equatorial crests.

Neosartorya galapagensis Frisvad, S.B Hong and Samson. sp. nov. (Fig. 4).

Species homothallica; ascomata luteo-alba, globosa vel subglobosa, 90-200 $\mu \mathrm{m}$ diam,. hyphis hyalinis vel luteolis laxe textis circumdata. Asci 8-spori, globosi vel subglobosi, $12-15 \mu \mathrm{m}$ diam; ascosporae late lenticulates, $c a$. $5 \mu \mathrm{m}$ diam, duabus cristis distantibus $1-2 \mu \mathrm{m}$ latis praeditae, valvis exigue tuberculatis. Conidiophora singula vel funiculosa, levia, 2-4 $\mu \mathrm{m}$ lata; conidiorum capitula columnaria, brevia, uniseriata; vesiculae subclavatae, 4-11 $\mu \mathrm{m}$ diam. Phialides lageniformes, 5-7 $\times 2-3 \mu \mathrm{m}$, dimidium superius vesiculae occupantes. Conidia globosa vel subglobosa, levia vel exigue asperulata, 2.3$3.0 \mu \mathrm{m}$ diam.

Holotype of $N$. galapagensis, here designated as CBS $117522^{\mathrm{T}}$ (IBT $\left.16756=\mathrm{KACC} 41935\right)($ dried culture), isolated from soil, Galapagos Islands, Ecuador, D. Mahooney.

Colonies on MEA 28-35 mm in diam. after 7 days at $25^{\circ} \mathrm{C}$ and more than $70 \mathrm{~mm}$ after 7 days at $37^{\circ} \mathrm{C}$, funiculose in texture, yellowish white (3A12). Conidiophores sparse, cleistothecial initials produced after $c a .10$ days of incubation. Colonies on CYA $27-40 \mathrm{~mm}$ in diam. after 7 days at $25^{\circ} \mathrm{C}$ and $61-$ $65 \mathrm{~mm}$ after 7 days at $37^{\circ} \mathrm{C}$, strongly funiculose in texture and white with a golden yellow (5B78) reverse without diffusible pigment. Conidial heads columnar. Conidiophores arising from bundles of aerial hyphae or the basal mycelium, smooth walled, up to $100 \mu \mathrm{m}$ long, 2-4 $\mu \mathrm{m}$ in width; vesicles 4-11 $\mu \mathrm{m}$ (sub)clavate with 5-7 $\mu \mathrm{m}$ flask-shaped phialides which are fertile on the upper half to twothirds of the surface. Conidia 2.3-3.0 $\mu \mathrm{m}$, globose to subglobose and the surface usually smooth. Cleistothecia yellowish white (4A2), globose to subglobose, 90-200 $\mu \mathrm{m}$ in diam., surrounded by a loose covering of aerial hyphae. Peridium consisting of angular cells, 3-8 $\mu \mathrm{m}$ in diam.; asci 8-spored, globose to subglobose, $12-15 \mu \mathrm{m}$ in diam.; ascospores broadly lenticular, spore body ca. $5 \mu \mathrm{m}$ in diam. with two distinct equatorial crests 1-2 $\mu \mathrm{m}$ wide, convex surface of ascospores microtuberculate.

Extrolite profile: All isolates examined in the species produce several gregatins and several partially characterized secondary metabolites. This species is chemically very distinct and different from the other species in section Fumigati or Neosartorya species. The gregatins have also been found in $A$. panamensis (Anke et al. 1980, 1988). The latter species was placed in Aspergillus section Usti by Raper and Fennell (1965).

Additional isolates: CBS $117521=$ IBT 16763 = KACC 41936, ex soil, Galapagos Islands, Ecuador.

Distinguishing features: The Aspergillus anamorph arising in bundles of aerial hyphae and the ascospores with two wide conspicuous equatorial crests and microtuberculate convex surface. 
Aspergillus turcosus S.B. Hong, Frisvad and Samson. sp. nov. (Fig. 5).

Coloniae in agaro maltoso ad $42-51 \mathrm{~mm}$ diam postseven dies $25^{\circ} \mathrm{C}, 70 \mathrm{~mm}$ diam $37^{\circ} \mathrm{C}$. Coloniae velutinae, griseo-glaucae vel griseo-virides, plerumque planae; reversum luteo-aurantium vel griseo-aurantium. Conidiophora levia, 4-7 $\mu \mathrm{m}$ lata. Conidiorum capitula columnaria, brevia, uniseriata; vesiculae globosae vel subclavatae, $15-25 \mu \mathrm{m}$ diam. Phialides lageniformes, 6-8 $\times 2-3 \mu \mathrm{m}$, duo tertia superiora vesiculae occupantes. Conidia subglobosa vel ovoidea, levia, 2.5-3.5 $\mu \mathrm{m}$ diam.

Holotype of A.turcosus, here designated as KACC $42091^{\mathrm{T}}$ (=IBT 27921) (dried culture) isolated from home air conditioner, Seoul, South Korea.

Colonies on MEA 42-51 mm in diam. after 7 days at $25^{\circ} \mathrm{C}$ and more than $70 \mathrm{~mm}$ after 7 days at $37^{\circ} \mathrm{C}$. Colony texture velvety, gray-turquoise to gray-green
(24-25B3-5) and usually plane. In reverse, colonies are yellowish orange (4B6) to grayish orange (5B6). Colonies on CYA attain a diam. of $38-41 \mathrm{~mm}$ after 7 days at $25^{\circ} \mathrm{C}$ and more than $70 \mathrm{~mm}$ after 7 days at $37^{\circ} \mathrm{C}$. Colony texture is velvety. Colony texture and color similar to that on MEA. In reverse, colonies are deep yellow (4A78). Conidial heads loose and short columnar. Conidiophores smooth-walled, up to $80 \mu \mathrm{m}$ long and 4-7 $\mu \mathrm{m}$ wide. Vesicles are 15-25 $\mu \mathrm{m}$ in diam., flask-shaped to globose, bearing 6-8 $\mu \mathrm{m}$ flask-shaped phialides over two-thirds of the surface. Conidia are subglobose, ovoid and smooth, 2.5-3.5 $\mu \mathrm{m}$ in diam.

Extrolite profile: Kotanins and several unique compounds but not yet elucidated secondary metabolites.

Additional isolates: KACC $42090=$ IBT 27920, KACC 41955 = IBT 3016.
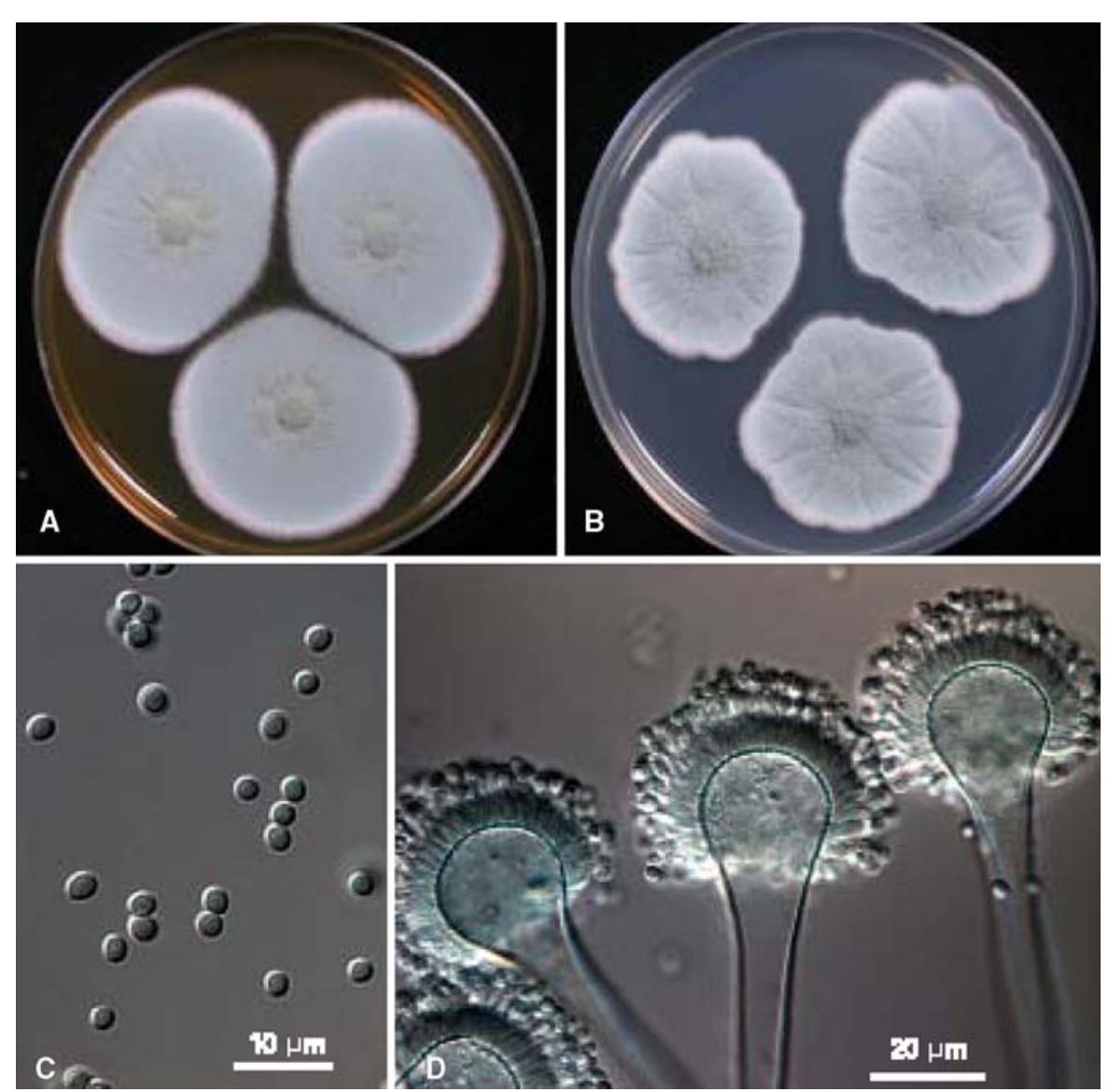

Fig. 5 Aspergillus turcosus sp. nov. (A) and (B) colonies on MEA (A) and CYA (B) after 7 days at $25^{\circ}$ C, $(\mathbf{C})$ conidia under a light microscope, (D) conidial heads 
Distinguishing features: Velvety colony, grayturquoise (green) color on CYA, phialides over two-third of the vesicle and growth at 10 and $50^{\circ} \mathrm{C}$ are distinctive characteristics of the species.

Acknowledgments This work was partly supported by the BioGreen 21 Program (Code \# 20050401034815) and the National Institute of Agricultural Biotechnology (Code \# 06-411-19-2), Rural Development Administration, Republic of Korea.

\section{References}

Anke H, Casser I, Schrage M, Steglich W (1988) Cyclogregatin, a new metabolite from Aspergillus panamensis. J Antibiot 41:1681-1684

Anke H, Schwab H, Achenbach H (1980) Metabolic products of microorganisms 197. Tetronic acid derivatives from Aspergillus panamensis. Production, isolation, characterization and biological activity. J Antibiot 33:931-939

Brakhage AA, Langfelder K (2002) Menacing mold: the molecular biology of Aspergillus fumigatus. Annu Rev Microbiol 56:533-455

Cole RJ, Cox RH (1981) Handbook of toxic fungal metabolites. Academic, New York

Felsenstein J (1995) PHYLIP (phylogeny inference package). Version 3.57c. Distributed by the author. Department of Genetics, University of Washington, Seattle

Frisvad JC, Samson RA (2004) Polyphasic taxonomy of Penicillium subgenus Penicillium. A guide to identification of food and air-borne terverticillate Penicillia and their mycotoxins. Stud Mycol 49:1-173

Frisvad JC, Thrane U (1987) Standardized high-performance liquid chromatography of 182 mycotoxins and other fungal metabolites based on alkylphenone indices and UV-VIS spectra (diode-array detection). J Chromatogr A 404:195-214

Geiser DM, Frisvad JC, Taylor JW (1998) Evolutionary relationships in Aspergillus section Fumigati inferred from partial $\beta$-tubulin and hydrophobin DNA sequences. Mycologia 90:831-845

Glass NL, Donaldson GC (1995) Development of primer sets designed for use with the PCR to amplify conserved genes from filamentous ascomycetes. Appl Environ Microbiol 61:1323-1330

Hillis DM, Bull JJ (1993) An empirical test of bootstrapping as a method for assessing confidence in phylogenetic analysis. Syst Biol 42:182-192

Hong SB, Cho HS, Shin HD, Frisvad JC, Samson RA (2006) New Neosartorya species isolated from soil in Korea. Int J Syst Evol Microbiol 56:439-442

Hong SB, Go SJ, Shin HD, Frisvad JC, Samson RA (2005) Polyphasic taxonomy of Aspergillus fumigatus and related species. Mycologia 97:1342-1355

Horie Y, Abliz P, Fukushima K, Okada K, Takaki GMC (2003) Two new species of Neosartorya from Amazonian soil, Brazil. Mycoscience 44:397-402
Horie Y, Miyaji M, Nishimura K, Taguchi H, Udagawa S (1993) Aspergillus fumisynnematus, a new species from Venezuelan soil. Trans Mycol Soc Jpn 34:3-7

Kimura M (1980) A simple method for estimating evolutionary rate of base substitutions through comparative studies on nucleotide sequences. J Mol Evol 2:87-90

Kornerup A, Wanscher JH (1978) Methuen handbook of color, 3rd. Eyre Methuen, London

Lee SB, Taylor JW (1990) Isolation of DNA from fungal mycelia and single spores. In: Innis MA, Gelfand DH, Sninsky JJ, White TJ (eds) PCR protocols: a guide to methods and applications. Academic, San Diego, pp 282-287

Peterson SW (1992) Neosartorya pseudofischeri sp. nov. and its relationship to other species in Aspergillus section Fumigati. Mycol Res 96:547-554

Peterson SW (2000) Phylogenetic relationships in Aspergillus based on rDNA sequence analysis. In: Samson RA, Pitt JI (eds) Integration of modern taxonomic methods for Penicillium and Aspergillus classification. Harwood Academic Publishers, Amsterdam, pp 323-355

Pitt JI, Samson RA, Frisvad JC (2000) List of accepted species and their synonyms in family Trichomaceae. In: Samson RA, Pitt JI (eds) Integration of modern taxonomic methods for Penicillium and Aspergillus classification. Harwood Academic Publishers, Amsterdam, pp 9-49

Raper KB, Fennell DI (1965) The genus Aspergillus. Williams and Wilkins, Baltimore

Saitou N, Nei M (1987) The neighbor-joining method: a new method for reconstructing phylogenetic trees. Mol Biol Evol 4:406-425

Samson RA (2000) List of names of Trichocomaceae published between 1992 and 1999. In: Samson RA, Pitt JI (eds) Integration of modern taxonomic methods for Penicillium and Aspergillus classification. Harwood Academic Publishers, Amsterdam, pp 73-79

Samson RA, Hoekstra ES, Frisvad JC (eds) (2004) Introduction to food- and airborne fungi, 7th edn. Centraalbureu voor Schimmelcultures, Utrecht

Samson RA, Nielsen PV, Frisvad JC (1990) The genus Neosartorya: differentiation by scanning electron microscopy and mycotoxin profiles. In: Samson RA, Pitt JI (eds) Modern concepts in Penicillium and Aspergillus classification. Plenum, New York, pp 455-467

Smedsgaard J (1997) Microscale extraction procedure for standardized screening of fungal metabolite production in cultures. J Chromatogr A 760:264-270

Swofford T (2000) PAUP*: Phylogenetic analysis using parsimony. Version 4.0. Sinaur Associates, Sunderland, MA, USA

Thompson JD, Higgins DG, Gibson TJ (1994) CLUSTAL W: improving the sensitivity of progressive multiple sequence alignment through sequence weighting, position specific gap penalties and weight matrix choice. Nucl Acids Res 22:4673-4680

Turner WB, Aldridge DC (1983) Fungal metabolites II. Academic, New York

Varga J, Vida Z, Toth B, Debets F, Horie Y (2000) Phylogenetic analysis of newly described Neosartorya species. Antonie van Leeuwenhoek 77:235-239 